\title{
Gaya kepenulisan Pramoedya: Stilistika atas roman Bumi Manusia
}

\author{
Ardik Ardianto* \\ Magister Linguistik, Fakultas Ilmu Budaya, Universitas Gadjah Mada, Indonesia \\ ardikardianto@gmail.com \\ *Corresponding author: ardikardianto@gmail.com
}

\begin{abstract}
Sejarah Artikel Diterima: 26 Maret 2020 Direvisi: 6 April $2020 \quad$ Tersedia Daring: 22 April 2020 ABSTRAK

Novel Bumi Manusia karya Pramoedya Ananta Toer sarat akan penarasian berbagai representasi kolonial, misalnya hegemoni bahasa, dan diskriminasi rasial. Penelitian ini bertujuan untuk menunjukkan bagaimana diksi suatu kata tidak hanya digunakan sebagai pendukung pelataran tetapi jauh di dalamnya mampu menjadi sarana pengungkap kedua representasi tersebut. Sumber data utama yang digunakan adalah roman Bumi Manusia. Data utama yang ditelaah adalah pilihan diksi Pramoedya, baik berupa kata, frasa, maupun klausa yang kemudian dianalisis berdasarkan beberapa aspek, yakni terminologi, etimologi, dan konteks sosio-historisnya. Beberapa sumber referensi, seperti Kamus Besar Bahasa Indonesia dan beberapa artikel atau buku penunjang, digunakan sebagai sumber data sekunder. Pemerian hasil temuan yang disajikan dalam makalah ini secara sederhana menunjukkan bahwa diksi bukan merupakan pilihan kata yang netral tanpa ada muatan apa pun di dalamnya; bagaimana diksi yang digunakan oleh sang penulis mampu merepresentasikan hegemoni bahasa, diskriminasi rasial, serta keadaan sosial budaya era Kolonial Hindia Belanda. Bagi mereka yang hidup sebagai zeitgeist (anak jaman) yang hidup dengan situasi, kondisi, dan semangat pada masa kolonial, pertemuan dua budaya atau lebih (yang diwakili oleh peradaban Barat dan Timur) mampu merekonstruksi ulang pola pandang dan nilai budaya, sehingga melahirkan kosakata-kosakata baru bahkan bahasa baru untuk mewakili realitas tersebut. Adapun bagi mereka yang hidup tidak sebagai zeitgeist masa itu, penggunaan kosakata-kosakata baru tersebut mampu menjadi wahana dalam menangkap representasi budaya yang terkandung di dalamnya.

Kata Kunci Bumi Manusia, Poskolonial, Representasi, Stilistika

ABSTRACT

Novel Bumi Manusia which was written by Pramoedya Ananta Toer, highly narrates a variety of colonial representations, i.e., language hegemony, and racial discrimination. This study aimed at disclosing how lexical choices/dictions are not merely used to support the background/setting nuance; instead they, in some degree, can unfold such representations. The primary data in this study were stylistic choices used by Pramoedya, i.e., words, phrases, clauses, even sentences, in the novel. The data, further, were analysed based on several aspects, including its terminology, etymology, and its sociohistorical context. Several references, e.g., Kamus Besar Bahasa Indonesia and relevant articles or books, were used to support the elaboration so as to grasp a deeper understanding. The findings showed that diction is, in fact, not a neutral vehicle without any contextual tendency within; how diction used can represent language hegemony, racial discrimination, and sociocultural settings in the Dutch Colonial era. For ones living in the colonial zeitgeist, the emergence of two cultures or more (primarily represented by Western and Eastern cultures) could reconstruct cultural values and norms, thus creating a novelty of terminologies to represent the reality. Meanwhile, for ones living outside this zeitgeist, the use of such terminologies appeared as a vehicle to grasp the cultural representation embodied within.
\end{abstract}

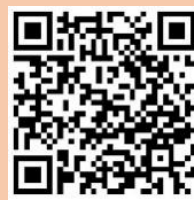

Copyright@2020, Ardik Ardianto This is an open access article under the CC-BY-3.0 license

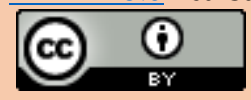

\begin{tabular}{|c|c|}
\hline Keywords & Bumi Manusia, Post-colonial, Representation, Stylistics \\
\hline How to Cite & Ardianto, A. (2020). Gaya kepenulisan Pramoedya: Stilistika atas roman Bumi Manusia. KEMBARA: \\
\hline & $\begin{array}{l}\text { Jurnal Keilmuan Bahasa, Sastra, dan Pengajarannya, } \\
\text { https://doi.org/I0.222I9/kembara.v6iI.II688 }\end{array}$ \\
\hline
\end{tabular}

\section{PENDAHULUAN}

Semenjak relativitas linguistik mendapatkan perhatian lebih dalam studi kebahasaan, hubungan bahasa dan budaya semakin dipandang kuat saling mempengaruhi satu sama lain. Bahkan, pada spektrum tertentu, bahasa juga menjadi penanda eksistensi, jati diri, atau identitas penuturnya Gee (20I4) yang secara cermat terealisasikan dalam penggunaan bahasa sehari-hari-baik sebagai sarana informasi (transaksional informatif), sarana penguat ikatan sosial (interaksional) maupun sebagai sarana perwujudan 
ekspresi (Halliday \& Hasan, I989). Pada aspek lain, bahasa mampu mengekspresikan, merepresentasikan, dan menyimbolkan budaya (Kramsch \& Widdowson, 1998). Salah satu eksponen kongkret dari hubungan bahasa dan budaya ini terwujud dalam ilmu stilistika. Stilistika merupakan suatu kajian yang menghubungkan antara bentuk linguistik dan fungsi sastra yang sangat bergantung pada penilaian personal seorang pembaca terhadap suatu karya sastra. Ia lebih menekankan pada dialektika peran seorang person sebagai pembaca atau penikmat sastra dan pengamat linguistik. Tentunya, peran yang kedua ini tidak serta merta mengubah intuisi seorang penikmat sastra tetapi lebih kepada memperkuat, membentuk, serta mengarahkan intuisi tersebut kepada pemahaman yang lebih utuh (Leech \& Short, 200I). Stilistika juga merupakan suatu pendekatan kritis dengan menggunakan metode-metode ilmu linguistik dalam kaitannya dengan analisis suatu karya sastra (Barry, 2017). Karena menjadikan karya sastra sebagai bahan studinya, stilistika dapat digolongkan menjadi dua kategori utama, yakni stilistika puisi Leech (I969) dan stilistika prosa (Leech \& Short, 200I).

Setakat ini, penelitian stilistika dalam karya sastra prosa masih terbilang kurang diminati, terlebih sastra prosa poskolonial. Sastra poskolonial merupakan salah satu jenis sastra yang secara khas muncul di berbagai negara di belahan dunia, khususnya negara-negara bekas jajahan atau kolonisasi. Sastra jenis ini dapat dikatakan orisinal buah hasil pertemuan antara peradaban superior vis-à-vis peradaban inferior yang diawali sejak terbitnya suatu kajian tentang hegemoni peradaban Barat atas Timur (atau yang sering disebut Orientalisme) yang diprakarsai oleh Edward Said (2003). Bahkan, istilah hegemoni ini sendiriSaid meminjam istilah ini dari Antonio Gramsci-muncul sebagai fakta sejarah di mana peradaban Barat dengan semua kebesarannya (budayanya, bahasanya, kekuasaannya) mencoba memandang timur sebagai objek yang layak untuk direpresentasikan (Lihat lebih lanjut pada Prolog yang disampaikan Edward Said untuk edisi ulang tahun Orientalisme yang ke-25). Nah, beberapa kesusastraan poskolonial—disebut beberapa karena banyak pakar memandang sastra poskolonial ini berada dalam dua posisi biner: yang satu merupakan agenda untuk melawan representasi bentukan yang diproduksi oleh peradaban Barat sebagai penjajah (atau yang sering disebut oksidentalisme); dan yang lainnya hanya sekedar turunan atau perpanjangan tangan dari diskursif peradaban Barat (bukan sebagai counterpart-nya) (lihat lebih lanjut pada Ashcroft, Griffiths, \& Tiffin, 2003)—ini seolah-olah menjadi wacana pembalik diskursif Barat.

Sastra poskolonial bisa dikenali idiosinkrasinya dari tiga tahapan: yakni, (I) tahap 'adopt' di mana sang penulis karya sastra bertendensi mengadopsi secara penuh bentuk otoritas Barat entah dalam bentuk bahasa maupun norma-norma budaya; (2) tahap 'adapt' di mana sang penulis sudah mulai mengadaptasikan otoritas Barat tersebut kepada nilai-nilai budaya lokal; dan yang terakhir, (3) tahap 'adept' di mana sang penulis sepenuhnya mendeklarasikan kemerdekaan budaya lokalnya sebagai wacana pembalik diskursif Barat (Barry, 2017). Menurut Barry, ketiga fase ini mampu ditemukan di semua genre karya sastra poskolonial mengingat idiosinkrasinya yang selalu berpusat pada interaksi dua budaya atau lebih (yang satu lebih superior dari yang lain) sebagai hasil dari proses penjajahan atau kolonisasi. Salah satu novel yang sarat menunjukkan ketiga tahapan ini adalah novel Bumi Manusia (2002) karya Pramoedya Ananta Toer.

Novel Bumi Manusia (2002) mengangkat latar belakang sejarah pra-kemerdekaan Indonesia yang sarat akan nilai-nilai nasionalisme dan kolonialisme (Farhana \& Aflahah, 2019), kelas sosial (Hastuti, 2018; Nisa, 2019), rasisme (Ridwan \& Sofianto, 2019), dan emansipasi (Akbar, 2019; Rahayu, Muliawati, \& Pujiatna, 2019). Kesemua nilai ini terealisasi tidak hanya melalui struktur wacana dan pelataran, tetapi juga melalui gaya kebahasaan Pramoedya di dalam novel. Kolonialisme dan rasisme, misalnya, sangat jelas tergambarkan pada penggunaan diksi dikotomi rasial Totok, Indo, dan Pribumi. Ketiga kata ini tidak hanya merepresentasikan sejarah kelam kolonialisme, tetapi juga dalam titik tertentu memerikan suatu sistem hegemoni di berbagai lini—baik dalam lini hukum, sosial, bahkan bahasa. Sistem hegemoni ini tentunya melibatkan pertalian antara 'penjajah' di satu sisi dan 'yang terjajah' di sisi lain. Di samping penggunaan diksi dikotomi ini, dalam novel Bumi Manusia (2002) ini peneliti menemukan pula adanya kecenderungan penggunaan bahasa-bahasa asing, misalnya bahasa Belanda dan bahasa Inggris, guna mendukung penggambaran latar cerita pada masa kolonial. Dalam hal ini, peneliti berasumsi bahwa 
penggunaan bahasa-bahasa asing tersebut tidak hanya berfungsi sebagai pendukung pelataran semata, tetapi lebih jauh lagi diasumsikan sebagai representasi hegemoni bahasa yang terjadi pada masa tersebut. Di samping itu, peneliti juga berasumsi bahwa interferensi bahasa asing tersebut digunakan untuk menggambarkan kepribadian Minke yang cenderung bersifat mimikri dengan segala sistem kebudayaan Barat. Karenanya, dengan berangkat pada dua asumsi dasar ini, penelitian ini bertujuan untuk menunjukkan bagaimana diksi Pramoedya dalam novel Bumi Manusia (2002) tidak hanya digunakan sebagai pendukung pelataran tetapi jauh di dalamnya mampu menjadi sarana pengungkap representasi kolonial, khususnya pada representasi hegemoni bahasa dan diskriminasi sosial.

Dengan meminjam teori pembabakan penulis poskolonial Barry (2017), analisis poskolonial pada novel Bumi Manusia (2002) ini meliputi (I) bagaimana pertalian representasi budaya digambarkan dalam suatu karya sastra—baik dari sudut pandang budaya superior 'penjajah' maupun dari sudut pandang budaya inferior 'terjajah'; (2) bagaimana pengaruh budaya superior mampu mempengaruhi seorang penulis dalam menghasilkan karya sastra poskolonial; (3) bagaimana pergeseran sudut pandang penulis (dari yang awalnya mengadopsi, mengadaptasi, dan akhirnya mendeklarasikan kemerdekaan budayanya sendiri) tercermin pada karya-karya poskolonialnya.

Penelitian terkait karya sastra poskolonial pernah dilakukan sebelumnya. Penelitian relevan yang pertama yakni penelitian yang menyoroti secara khusus rasisme dalam novel Bumi Manusia yang dilakukan oleh (Ridwan \& Sofianto, 2019). Penelitian ini berbeda dengan penelitian relevan pertama dalam segi cakupan telaahannya-penelitian relevan pertama hanya menyoroti aspek rasisme dalam novel, sedangkan pada penelitian ini menyoroti juga aspek hegemoni bahasa dan babakan penulis poskolonial. Di samping itu, aspek rasisme yang ditelaah juga berbeda mengingat pada penelitian ini representasi hegemoni rasial hanya diturunkan dari telaah pilihan diksi. Penelitian relevan kedua diambil dari penelitian (Hartono, 2017) terkait konsep mimikri dan hibriditasi dalam novel Burung-Burung Manyar. Perbedaan pada penelitian relevan yang kedua ini terletak pada cakupan telaah mimikri dan hibridasi dalam novel. Penelitian Hartono berfokus pada mimikri dan hibriditasi dalam berbagai ranah, sedangkan pada penelitian ini hanya difokuskan pada mimikri dan hibriditasi berbahasa. Terakhir, terkait penelitian stilistika, penulis menyajikan tiga penelitian relevan. Pertama, penelitian terkait stilistika dalam novel sastra indie (Adenan, Kayad, \& Daud, 2019). Penelitian ini menunjukkan bahwa diksi memiliki beberapa peran kunci, seperti mendukung pelataran dan perwatakan. Kemudian, penelitian yang dilakukan oleh Arti (2015) juga menyimpulkan bahwa penggunaan gaya bahasa seperti simile, metafora, hiperbola, metonimia, sarkasme, aliterasi, serta eufemisme mampu memberikan nilai estetika tersendiri terhadap gaya Narko Budiman dalam novelnya Rembulan Ndhuwur Blumbang. Terakhir, Subroto (1997) juga menunjukkan bahwa struktur kata yang cenderung singkat, pendek-pendek mampu memudahkan pemerian alur dan peristiwa yang terjadi dalam karya prosa. Mereka juga menemukan bahwa pemilihan kosakata (diksi) serta sapaan juga mampu mencerminkan sosial budaya yang terkandung di dalam suatu karya prosa. Perbedaan ketiga penelitian yang telah disebutkan sebelumnya dengan penelitian ini terletak pada objek penelitian dan kajian poskolonial. Meski demikian, hasil temuan ketiga penelitian tersebut digunakan sebagai pembanding atas hasil temuan penelitian ini.

Dengan mempertimbangkan berbagai penjabaran ini, novel Bumi Manusia(2002) menjadi sangat menarik untuk dikaji dari perspektif stilistika dan kaitannya dengan kajian poskolonial, terlebih ketika hal ini sesuai dengan tujuan penelitian ini, yakni menelaah penggunaan diksi Pramoedya Ananta Toer dalam novel Bumi Manusia (2002). Hasil penelitian ini diharapkan mampu berkontribusi dalam studi stilistika, terlebih pada hubungan pilihan diksi sebagai eksponen dari telaah linguistik dan representasi nilai sosio-historis yang diwakilinya. Lebih lanjut, hasil penelitian ini juga diharapkan mampu menjadi pendukung materi pembelajaran bahasa dan budaya, terlebih pada paradigma Relativisme Linguistik.

\section{METODE}

Penelitian ini merupakan penelitian stilistika dengan titik tolak atas relasi dua sumbu utama, yakni kajian stilistika dan kajian poskolonial. Kajian stilistika, dalam hal ini, merujuk pada gaya kebahasaan 
Pramoedya Ananta Toer dengan fokus yang lebih sempit pada pemilihan diksinya, berdasarkan satu dari empat kategori stilistika dari Leech \& Short (200I). Adapun kajian poskolonial merujuk secara khusus pada teori seri babakan penulis sastra poskolonial adobt, adapt, dan adept (Barry, 2017). Sumber data utama yang digunakan pada penelitian ini adalah roman pertama dari seri tetralogi Pulau Buru karangan Pramoedya Ananta Toer, yakni novel Bumi Manusia (2002). Data utama yang ditelaah adalah pilihan diksi Pramoedya, baik berupa kata, frasa, maupun klausa. Data utama ini kemudian dianalisis berdasarkan beberapa aspek, yakni terminologi, etimologi, dan konteks sosio-historisnya. Beberapa sumber referensi, seperti Kamus Besar Bahasa Indonesia (KBBI) dan beberapa artikel atau buku penunjang, digunakan sebagai sumber data sekunder guna mendukung penjelasan utama untuk mendapatkan pemahaman yang lebih mendalam. Data dijabarkan secara deskriptif dalam bentuk pemerian, yang kemudian disajikan berdasarkan tiga kategori utama dalam merepresentasikan sastra poskolonial.

\section{HASIL DAN PEMBAHASAN}

\section{Diksi seorang Pramoedya Ananta Toer dalam Roman Bumi Manusia}

Sebelum memberikan pemerian terkait diksi Pramoedya dalam roman Bumi Manusia (2002), perlulah peneliti tekankan bahwa cakupan diksi yang diteliti hanya terletak pada diksi yang mampu menggambarkan representasi sastra poskolonialnya. Dus, dalam hal ini diksi Pramoedya akan dibagi menjadi tiga kategori utama, yakni (a) diksi sebagai pengungkap representasi hegemoni bahasa, (b) diksi sebagai pengungkap representasi diskriminasi rasial Hindia Belanda, serta (c) pergeseran makna.

\section{Diksi: Pengungkap Representasi Hegemoni Bahasa}

Dalam merepresentasikan adanya suatu hegemoni bahasa, yakni penggunaan bahasa Eropa seperti Inggris, Perancis, dan Belanda, beberapa leksikon digunakan sebagai berikut:

Kata Minke, meski tidak dituliskan dalam cetak miring, namun Pramoedya memberikan catatan kaki pada kata ini. Kata Minke sendiri merupakan sebuah nama dari tokoh utama roman ini. Yang menarik untuk dilihat dalam penyebutan nama ini adalah bagaimana Pramoedya memberikan catatan kaki terkait pelafalan kata Minke ini (Catatan kaki Pramoedya Minke baca: Mingke) (Toer, 2016). Bahkan penamaan Minke di sini merupakan buah hasil pelafalan bahasa Inggris yang tidak dapat diucapkan secara benar guna memberikan kesan buruk bagi tokoh utama.

\footnotetext{
"Meneer Rooseboom melotot menakutkan, membentak: diam kau, monk... Minke!' "Enam bulan lamanya, dan aku temukan kesamaan bunyi dan huruf pada namaku...dan aku teringat pada Meneer yang agak ragu menyebut nama itu...ia mungkin bermaksud memaki aku dengan kata monkey." (Ibid., hlm. $5 \mathrm{I}-52)$
}

Kutipan ini menunjukkan secara tersirat bahwa kata Minke merupakan turunan kata yang diadopsi dari Bahasa Inggris Monkey yang tidak diucapkan secara benar oleh Meneer (pendidik) Rooseboom. Jadi tidak mengherankan ketika Pramoedya memberikan catatan kaki terkait pelafalan nama Minke ini-alih-alih dibaca secara ortografi /minkə/ sebagaimana pelafalan bahasa Indonesia, pelafalan yang dipakai adalah /minkə/ dengan mengadopsi $\eta$ dalam bahasa Inggris. Pelafalan seperti ini juga terlihat ketika Pramoedya memberikan catatan kaki pada nama Jean Marais—catatan kaki Pramoedya Jean Marais, baca: Syang Maré (Ibid., hlm. I9)—yang bertendensi ke pelafalan dalam bahasa Perancis.

Contoh kedua adalah kata H.B.S. (Ibid., hlm. I7) dan E.T.S. (Ibid., hlm. 35) yang merupakan singkatan dari 'Hogere Burger School' dan 'Europeesche Lagere School'. Kedua sekolah ini merupakan pendidikan tingkat menengah yang ditujukan bagi orang Belanda, Eropa, dan elite pribumi pada masa itu. Alih-alih menggunakan istilah bahasa Indonesia, Pramoedya lebih cenderung menggunakan istilah aslinya dalam bahasa Belanda. Hal demikian juga terjadi pada kasus singkatan S.I.B.A. (tanpa cetak miring) yang 
diberikan catatan kaki oleh sang penulis—catatan kaki Pramoedya, S.I.B.A. (Belanda): School voor Inlandsche Bestuursambtenaren. Sekolah Calon Pejabat Pangreh Praja Pribumi (Ibid., hlm. I88).

Selanjutnya, diksi vokatif Mevrouw yang diberikan catatan kaki oleh Pramoedya-Mevrouw (Belanda): Nyonya. Juffrouw: Nona. Berhubung waktu itu kata Nyonya belum dipergunakan dalam Melayu di sini dipergunakan kata asli (Ibid., hlm. I9)—menunjukkan bahwa sang penulis bertendensi menggunakan istilah asli yang digunakan pada masa itu (bandingkan dengan terjemahannya dalam bahasa Inggris This Earth of Mankind karya Max Lane (1996) yang diartikan sebagai Mrs. tanpa menggunakan istilah aslinya Mevrouw). Mungkin alasan utama Pramoedya mempertahankan diksi vokatif ini adalah untuk menunjukkan adanya pertalian antara suatu kata dengan realitas hukum yang berlaku pada masa itu—hal ini akan dibahas selanjutnya di bagian 'Pergeseran Makna'.

"Dekat di belakang pagar kayu terpasang papan nama besar dengan tulisan:

Boerderij Buitenzorg" "Dari nama Buitenzorg itu ia mendapatkan nama.

Ontosoroh—sebutan Jawa." (Ibid., hlm. 24-25)

Dari kutipan di atas, kita dapat kenali bahwa meski dengan istilah yang sama, yakni Buitenzorg, Pramoedya menuliskannya dengan berbeda: yang satu dengan cetak miring, yang lain tidak. Pramoedya memberikan catatan kaki terkait frasa yang dicetak miring — catatan kaki Pramoedya, Boerderij Buitenzorg (Belanda): Perusahaan Pertanian. Di sini, sang penulis menggunakan istilah aslinya dengan dua tujuan: pertama, istilah asli ini digunakan untuk menggambarkan bahwa pada masa itu, untuk istilah-istilah yang terkait modernitas Eropa digunakan bahasa superior yakni bahasa Belanda; yang kedua, istilah asli ini penulis gunakan untuk menjelaskan mengapa Nyai Ontosoroh dalam roman Bumi Manusia lebih dikenal publik sebagai Ontosoroh ketimbang nama aslinya, yakni Sanikem.

Hal demikian juga terjadi pada beberapa diksi istilah seperti onder curatelee dan Een Buitengewoon Gewoone Nyai die Ik ken (keduanya dicetak miring) seperti pada penggalan kutipan berikut:

(I) “...bagaimana nanti? Kalau ayahmu ternyata memang gila dan oleh Hukum ditaruh order curatelee? Seluruh perusahaan, kekayaan dan keluarga akan diatur seorang curator yang ditunjuk oleh Hukum.” (Ibid., hlm. I I2)

(2) "Nyai datang menyertai kami. Selembar koran S.N. v/d D ada di tangannya. Ia tunjukkan padaku sebuah cerpen Een Buitengewoon Gewoone Nyai die Ik ken." (Ibid., hlm. I62)

Dari penggalan kutipan pertama, Pramoedya mempertahankan istilah aslinya dengan pretensi bahwa memang pada istilah-istilah hukum, bahasa superior (dalam konteks ini adalah bahasa Belanda) selalu digunakan. Dengan mempertahankan istilah aslinya, pembaca dapat mengetahui bahwa suatu istilah dapat merepresentasikan suatu norma hukum yang berlaku pada masa dan tempat tertentu. Dalam kasus ini, merujuk pada catatan kaki yang diberikan oleh Pramoedya, onder curatelee merupakan bahasa Belanda yang berarti 'di bawah pengampunan'. Jika ditinjau lebih spesifik lagi, istilah ini secara hukum legal merujuk pada suatu keadaan kehilangan hak untuk menguasai dan memelihara barang miliknya, sehingga ditempatkan di bawah perwalian/kurator karena keadaan tidak mampu, gangguan jiwa atau sebab lainnya (Basiang, 2017).

Kutipan kedua, penggunaan bahasa Belanda pada judul cerpen yang dibuat Minke dalam terbitan suatu koran menunjukkan bahwa Pretensi Pramoedya dalam menggambarkan karakter Minke pada roman Bumi Manusia ini masih sangat bangga dengan identitas ke-Belandaannya. Dari sini dapat dilihat bagaimana fase pertama 'adopt'yang dijabarkan oleh Barry terkait tahapan penulis karya sastra poskolonial nyata terlihat dari gaya penulisan Pramoedya dalam menggambarkan sosok Minke. Meskipun dengan adanya catatan kaki yang dituliskan oleh sang penulis_catatan kaki Pramoedya, Een Buitengewoon Gewoone Nyai die Ik ken (Belanda): Seorang Nyai Biasa yang Luarbiasa yang Aku Kenal (Toer, 2016)_ 
tendensi Pramoedya dalam menggunakan bahasa Belanda menunjukkan bahwa sosok Minke dalam roman Bumi Manusia ini menunjukkan identitas ganda-meminjam istilah Berry tentang kepribadian ganda, identitas terbagi, atau identitas labil dalam bukunya Beginning Theory an Introduction to Literary and Cultural Theory (2017)_yang mungkin tak lagi dijumpai pada sekuel tetraloginya.

Dalam novel Bumi Manusia, penggunaan diksi asing, singkatan, maupun serapan tidak hanya digunakan sebagai penjelas pelataran tetapi juga digunakan sebagai gambaran adanya hubungan antara penggunaan bahasa, strata sosial, dan prestise. Bahasa-bahasa Eropa, seperti bahasa Inggris dan Belanda, diasosiasikan dengan segala hal yang bersifat modern, terdidik, dan terpelajar. Oleh karenanya, terminologi dalam administrasi negara maupun dalam hukum digunakan bahasa-bahasa Eropa ini, khususnya bahasa Belanda. Tidak terbatas hanya dalam ranah tersebut, diksi asing ini juga mampu menunjukkan prestise penuturnya. Pada beberapa dialog, misalnya, Minke mengeksplorasi sedemikian rupa diksi-diksi asing ini guna menunjukkan kebanggaannya pada ilmu pengetahuan Barat, berusaha meniru, dan menjadikannya sebagai bagian dari jati dirinya. Hal ini sejalan dengan hasil temuan penelitian Hartono (2017) pada tokoh Setadewa dalam novel Burung-Burung Manyar yang selalu berkomunikasi dengan Mayor Verbruggen dengan menggunakan bahasa Belanda. Proses mimikri ini, sebagaimana dijelaskan oleh Barry (20I7), merupakan fase poskolonial awal (adopt) yang tercermin pada banyak karya sastra poskolonial. Lebih lanjut, Bhabha (1984) menjelaskan bahwa "...colonial mimicry is the desire for a reformed, recognized Other, as a subject of a difference that is almost the same, but not quite." (mimikri kolonial merupakan hasrat sebagai Liyan yang dikenali, sebagai subjek perbedaan yang hampir sama namun tidak akan pernah sama, terj.). Ihwal perwatakan ini, diksi asing yang digunakan oleh Pramoedya untuk mencitrakan sosok Minke yang bangga akan ilmu pengetahuan Baratnya juga sejalan dengan hasil temuan Adenan et al. (2019) yang menjelaskan bahwa diksi asing yang digunakan oleh seorang tokoh pada suatu cerita mampu menggambarkan kepribadian atau wataknya.

\section{Diksi: Pengungkap Representasi Diskriminasi Rasial Hindia Belanda}

Selain merepresentasikan hegemoni bahasa, pemilihan diksi Pramoedya juga menggambarkan diskriminasi rasial Hindia Belanda pada masa pra-kemerdekaan. Meski tidak menggunakan istilah-istilah bahasa penjajah, yakni Bahasa Belanda, beberapa leksikon pilihan sang penulis memiliki tendensi ke arah pemerian yang cukup memadai terkait diskriminasi rasial yang terjadi di masa penjajahan Hindia Belanda. Beberapa diksi tersebut di antaranya:

Contoh pertama terkait dikotomi tripartit, Totok, Indo, dan Pribumi. Di sepanjang romannyabahkan di semua tetraloginya, mulai dari Bumi Manusia, Anak Semua Bangsa, Jejak Langkah, hingga Rumah Kaca—Pramoedya selalu menggunakan ketiga istilah ini untuk memberikan gambaran terkait diskriminasi rasial yang terjadi di sepanjang era penjajahan. Secara sederhana, Totok merupakan suatu kata sifat yang disandangkan pada sesuatu yang asli, sejati (bukan peranakan) (Sugono, 2008). Namun, jika dilihat jauh ke belakang, kata Totok merujuk pada pendatang atau orang asing yang hidup di negeri Hindia Belanda. Dalam suatu surat kabar De Telefoon tahun I886, misalnya, penggunaan istilah Totok sudah ada dan digunakan oleh masyarakat lokal guna merujuk pada pekerja VOC. Istilah Totok sendiri berasal dari bahasa Malay yang berarti 'tempurung kosong'. Betapa pun, satu hal yang pasti adalah bahwa penggunaan istilah Totok ini-meski tetap dipertanyakan etimologinya—selalu merujuk pada pendatang, khususnya mereka yang berkulit putih (Bosma, Raben, \& Shaffer, 2008). Istilah Indo merujuk pada ras peranakan. Secara etimologi, kata Indo ini merupakan singkatan yang disandangkan kepada 'Dutch IndoEuropean' yang berarti Eurasia yang cenderung diasosiasikan dengan istilah Sinyo (dibahas di bagian selanjutnya Pergeseran Makna) (Taylor, 1983). Dan yang terakhir terkait istilah Pribumi. Menarik untuk kita lihat bahwa Pramoedya lebih memilih menggunakan istilah Pribumi ketimbang Inlanderbandingkan dengan penggunaan diksi ini pada karya-karya Y.B. Mangunwijaya, terlebih pada novelnya Burung-Burung Manyar (1989). Menurut KBBI, Pribumi merupakan kata benda yang merujuk pada penduduk asli (warga negara penduduk asli suatu negara) (hlm. I24I). Adapun Frederick \& Worden (20I I) menjelaskan bahwa pribumi ini merupakan istilah khusus yang digunakan pada masa poskolonial 
untuk menggantikan kata Inlander yang berarti "penduduk asli" sebagaimana terlihat dalam kutipannya berikut.

Pribumi-Literally, an indigene, or native. A term coined in the post- colonial period to replace the Dutch word inlander, a term that also meant "native" but which did not refer to Arabs, Chinese, or Eurasians who might have been born in the Indies. The distinction between pribumi and non-pribumi has had significant implications for economic development policy. (hlm. 409)

Meskipun mungkin istilah ini mengalami pasang surut dalam konteks sejarah ${ }^{6}$, diksi Pribumi sendiri merupakan bentuk perlawanan (atau wacana pembalik) dari diskursif Barat yang diwakili oleh diksi Inlander. Dari sudut pandang perkembangannya, penggunaan kata Pribumi ini selalu berubah-ubah. Sejak kemerdekaan, misalnya, kata pribumi ini mendapatkan antonim binernya, yakni non-pribumi guna membedakan antara penduduk Indonesia asli dan penduduk Indonesia Tionghoa. Namun, sejak Inpres 26/I998 yang dikeluarkan oleh Presiden B.J. Habibie, kedua istilah ini (pribumi dan non-pribumi) dilarang penggunaannya guna menghilangkan kesan diskriminasi rasialnya. Dengan melihat sedikit lebih jauh latar belakang Pramoedya sebagai aktivis sejak pra-kemerdekaan hingga Orde Baru, kita akan dengan mudah menangkap alasan mengapa ia menggunakan diksi Pribumi ini. Selanjutnya adalah diksi Nyai yang sering Pramoedya gunakan untuk merujuk pada sosok Sanikem atau Ontosoroh, sebagaimana terlihat pada kutipan berikut.

“...rasanya siapa pun tahu, begitulah tingkat susila keluarga nyai-nyai: rendah, jorok, tanpa kebudayaan, perhatiannya hanya pada soal-soal berahi semata. Mereka hanya keluarga pelacur...Tapi Nyai Ontosoroh ini, dapatkah dia dikenakan pada anggapan umum ini?” (hlm. 75)

Dari kutipan di atas, diksi Nyai selalu diasosiasikan—setidaknya stigma masyarakat pada jaman kolonial—dengan pelacur, gundik penjajah. Definisi ini dikuatkan pula dengan penjabaran KBBI terkait istilah Nyai ini: bahwasanya Nyai merupakan kata benda yang merujuk pada gundik orang asing (terutama orang Eropa) (hlm. I080); karenanya, dari sini kita bisa lihat bagaimana diksi Nyai ini merepresentasikan diskriminasi rasial pada perempuan-perempuan pribumi yang dipersunting totok. Pun juga bahwa diksi Nyai ini selalu berjukstaposisi dengan diksi Mevrouw dalam konteks Hukum Hindia Belanda. Kedua diksi ini membawa konsekuensi hukum bak langit dan bumi dalam masa kolonial. Seorang Nyai tidak akan pernah mendapatkan semua hak yang didapatkan oleh Mevrouw-misalnya hak mendapatkan warisan, hak asuh anak, dll. Bahkan, gelar Nyai ini saja sudah mencerminkan status hukum seorang perempuan di Hindia Belanda, yakni tidak diakui sama sekali dan dianggap tidak ada.

Masih berkenaan dengan diksi Nyai di atas, Pramoedya juga menggunakan diksi 'mengakui'dan diberikannya sebuah catatan kaki sebagai berikut: mengakui (Belanda: erkennen), sehingga anak-anak itu menjadi "erkend natuurlijk kind" anak sedarah. Dalam kasus ini, diksi mengakui yang digunakan Pramoedya, alih-alih memiliki arti denotatif menerima dan menyatakan (KBBI, hlm. 3I), merujuk pada konsep Hukum Hindia Belanda untuk menjadikan anak(-anak) berstatus hukum sebagai anak sedarah. Karenanya, diksi mengakui ini erat kaitannya dengan konsep diskriminasi rasial yang terjadi pada merekamereka yang bergelar Nyai. Hal ini terlihat dalam penggalan kutipan berikut.

"Pada suatu hari aku dan Tuan datang ke Pengadilan untuk mengakui Robert dan kau sebagai anak Tuan Mellema. Pada mulanya aku menduga, dengan pengakuan itu anak-anakku akan mendapatkan pengakuan hukum sebagai anak syah. Ternyata tidak, Ann. Abangmu dan kau tetap dianggap anak tidak syah,..” (hlm. I36). 
Diskriminasi sosial pada novel Bumi Manusia cenderung direpresentasikan dengan penggunaan diksi rasial yang mendikotomikan antara satu strata sosial dengan strata sosial lainnya. Dikotomi rasial ini bisa berupa pelabelan, seperti Pribumi, Indo, atau Totok, atau bisa juga berupa kata sapaan, misalnya Mevrouw dan Nyai. Pelabelan dan kata sapaan disfemisme ini dirancang sedemikian rupa untuk mempertahankan sistem hegemoni kolonial atas kaum jajahannya. Hal ini terilustrasikan dalam sosok Nyai Ontosoroh yang karena statusnya sebagai seorang Nyai menjadikannya rendah secara moral di hadapan masyarakat. Tidak hanya berhenti pada stigma buruk saja, pelabelan kata $N_{y a i}$ pada dirinya menghilangkan status dirinya dalam hukum kolonial. Lebih lanjut, Nisa (2019) menjelaskan bahwa meskipun secara pribadi tegar, dalam lubuk hati Nyai Ontosoroh tetap terdapat rasa inferioritas perempuan yang diciptakan oleh stigma buruk dan ketidakadilan hukum kolonial atasnya. Kedua penelitian relevan, Ridwan dan Sofianto (2019) serta Subroto (1997), juga menunjukkan bahwa kata sapaan mampu mencerminkan keadaan sosial budaya suatu cerita. Pelabelan Pribumi pada Minke, misalnya, menjadikan Robert Suurhof (Peranakan Indo) dan Herman Mellema (Totok) semena-mena dan seolah memiliki derajat yang lebih superior dalam strata sosial (Ridwan \& Sofianto, 2019). Yang menarik untuk diperhatikan dalam hasil temuan penelitian ini adalah terdapat beberapa kondisi di mana pelabelan dan kata sapaan mampu mengalami pergeseran makna dari semantis menjadi pragmatis, misalnya pada kata sapaan Sinyo yang disandangkan oleh Nyai Ontosoroh pada Minke. Hal ini tidak ditemukan pada kedua penelitian relevan.

\section{Pergeseran Makna}

Pada bagian ini ada dua poin utama yang akan disampaikan, yakni terkait pergeseran makna Mevrouw dan Sinyo yang sering digunakan oleh Pramoedya di roman Bumi Manusia. Contoh pertama terkait diksi Mevrouw yang telah dijelaskan di muka: bahwa diksi Mevrouw ini merupakan polisemi dari dua peran: (I) sebagai kata sapaan dalam bahasa Belanda sebagaimana dijelaskan pada catatan kaki Pramoedya; dan (2) sebagai status hukum seorang istri di mata pengadilan. Sebagai status hukum, diksi Mevrouw sebagaimana telah dijelaskan sebelumnya akan selalu berjukstaposisi dengan diksi Nyai, mengingat keduanya merupakan oposisi biner di depan pengadilan—yang satu memiliki status hukum dan karenanya secara otomatis dikenai konsekuensi hukum (baik kewajiban atau hak) yang melekat padanya; sedangkan yang lainnya tidak dianggap sama sekali di mata pengadilan. Dengan memperhadapkan kedua diksi ini (Mevrouw vis-à-vis Nyai) Pramoedya seolah-olah mencoba menghidupkan kembali fakta sosio-historis akan sistem hukum rasial yang digunakan oleh penjajah. Hal ini terlihat pada cuplikan kutipan berikut.

"Untuk selamanya takkan ada orang akan memanggil aku Mevrouw. Panggilan Nyai akan mengikuti aku terus, seumur hidup. Tak apa asal kalian mempunyai ayah cukup terhormat, dapat dipegang, dapat dipercaya, punya kehormatan." (Ibid., hlm. I37)

Contoh kedua terkait diksi Sinyo. Jika merujuk pada definisi denotatifnya, Sinyo merupakan kata benda yang merujuk pada anak lelaki yang belum kawin (bangsa Eropa atau peranakan Eropa) (KBBI, hlm. I466). Adapun merujuk pada etimologinya, leksikon Sinjo (ejaan baru Sinyo) diturunkan dari bahasa Portugis senhor, yang digunakan pada masa kolonial sebagai istilah peyoratif bagi orang Eurasia atau Indo (Taylor, 1983). Namun di beberapa situasi, kata Sinyo ini digunakan oleh Pramoedya sebagai kata sapaan Nyai Ontosoroh kepada Minke (Toer, 2016),--meskipun kenyataannya Minke bukanlah anak keturunan Eropa atau pun peranakan Eropa. Secara lebih pragmatis, dengan menggunakan diksi ini sebagai sapaan kepada Minke, Pramoedya seolah-olah ingin menggambarkan bahwa kata Sinyo ini bisa memiliki makna pragmatis, yakni sapaan kepada siapa pun yang memiliki pengetahuan Barat—dalam konteks ini Minke memperkenalkan dirinya sebagai lulusan sekolah bergengsi H.B.S. Dengan adanya 
ambivalensi makna semacam ini, sekilas pembaca mungkin akan kebingungan untuk mendefinisikan diksi Sinyo tersebut.

Penggunaan diksi Pramoedya Ananta Toer dalam novel Bumi Manusia (2002) sangat erat kaitannya dengan representasi hegemoni kolonial atas masyarakat terjajah pada masa pra-kemerdekaan. Pramoedya sebagai pengarang dapat dikatakan tidak hanya menciptakan suatu karya sastra yang berorientasi pada keindahan; tetapi lebih dari itu ia berkehendak untuk menyampaikan pikiran, pendapat, serta pandangannya terhadap kolonialisme (Hartono, 2017). Tema-tema seperti anti-kolonialisme, pertentang antar kelas sosial, perjuangan keadilan, dan emansipasi menjadi tema-tema sentral tidak hanya dalam novel Bumi Manusia (2002), tetapi juga dalam karya-karya sastra Pramoedya lain—beberapa tema utama dalam karya-karya Pramoedya, misalnya emansipasi dalam novel Gadis Pantai (Muzakka, 2017), perjuangan dalam novel Arus Balik (Badio, Nurgiyantoro, \& Hartono, 2019), serta marginalitas dan perlawanan dalam novel Bukan Pasar Malam (Kusuma \& Atikah, 2017). Representasi hegemoni ini tidak hanya terwujud dalam bentuk hegemoni bahasa, tetapi juga dalam bentuk diskriminasi sosial.

\section{SIMPULAN}

Dengan mempertimbangkan kerangka teoretis pada fase babakan penulis sastra poskolonial yang diajukan oleh Barry, penelitian ini menyimpulkan bahwa Pramoedya dalam roman Bumi Manusia(2002) masih terkesan mengadopsi berbagai kebesaran peradaban Eropa (baik itu pengetahuan, nilai budaya, bahasa, norma kesusilaan, norma hukum, dsb.) sebagai latar roman—-terlebih ketika dipandang dari kacamata linguistik berkenaan dengan pemilihan diksi-diksi diskursif Barat. Setelah melihat bahwa diksi tidak hanya sebagai pilihan kata yang netral tanpa ada muatan apa pun di dalamnya, dapatlah diketahui bahwa bagi mereka yang hidup sebagai zeitgeist (anak jaman) yang hidup dengan situasi, kondisi, dan semangat pada masa tertentu, pertemuan dua budaya atau lebih mampu merekonstruksi ulang pola pandang, nilai budaya, norma kesusilaan, dsb.—entah itu menerima, menolak, atau ambivalen—karenanya, melahirkan kosakata-kosakata baru bahkan bahasa baru untuk mewakili realitas tersebut; sedangkan bagi mereka yang hidup tidak sebagai zeitgeist masa itu, penggunaan kosakata-kosakata tertentu tersebut mampu menjadi wahana dalam menangkap representasi budaya yang terkandung di dalamnya.

\section{UCAPAN TERIMA KASIH}

Peneliti berterima kasih kepada penyunting dan mitra bestari Jurnal KEMBARA yang telah bersedia memberikan masukan-masukan untuk perbaikan artikel ini.

\section{DAFTAR PUSTAKA}

Adenan, M. K., Kayad, F. G., \& Daud, M. Z. (2019). Analisis stilistik melalui penggunaan bahasa dalam novel sastera indie: Karya Azwar Kamaruzaman. Jurnal Kesidang, 3(I), I06-I2I. Retrieved from http://journal.kuim.edu.my/index.php/JK/article/view/3I5/27I

Akbar, V. K. (2019). Peran perempuan dalam novel Bumi Manusia karya Pramoedya Ananta Toer. Bahastra: Jurnal Pendidikan Bahasa dan Sastra Indonesia, 3(2), 232-236. Retrieved from https://jurnal.uisu.ac.id/index.php/Bahastra/article/view/I323/I027

Arti, L. W. (2015). Kajian stilistika novel Rembulan Ndhuwur Blumbang karya Narko "Sodrun" Budiman. ADITYA-Pendidikan Bahasa dan Sastra Jawa, 7(I), 22-27. Retrieved from http:// ejournal.umpwr.ac.id/index.php/aditya/article/view/2397/2247

Ashcroft, B., Griffiths, G., \& Tiffin, H. (2003). The empire writes back: Theory and practice in postcolonial literatures. London; New York: Routledge.

Badio, S., Nurgiyantoro, B., \& Hartono, H. (2019). Nilai perjuangan dalam novel Arus Balik karya Pramoedya Ananta Toer. Indonesian Language Education and Literature, 5(I), 33-46. doi: http://I0.24235/ileal.v5iI.3723

Barry, P. (2017). Beginning theory: An introduction to literary and cultural theory. Manchester: Manchester University Press. 
Basiang, M. (2017). The contemporary law dictionary (2nd ed.). Jakarta: Gramedia Pustaka Utama.

Bhabha, H. (1984). Of mimicry and man: The ambivalence of colonial discourse. JSTOR, 28(I), I25I33. doi: http:/ / I0.2307/778467

Bosma, U., Raben, R., \& Shaffer, W. (2008). Being" Dutch" in the Indies: A history of creolisation and empire, 1500-1920. Singapore: University of Hawaii Press.

Farhana, R., Farah , \& Aflahah, A. (2019). Kolonialisme dan nasionalisme dalam novel Bumi Manusia karya Pramoedya Ananta Toer. GHANCARAN: Jurnal Pendidikan Bahasa dan Sastra Indonesia, I(I), I0-25. doi: http://dx.doi.org/I0.I9I05/ghancaran.vIiI.2946

Frederick, W. H., \& Worden, R. L. (20I I). Indonesia: A country study. Washington: Federal Research Division, Library of Congress.

Gee, J. P. (20I4). An introduction to discourse analysis: Theory and method. New York: Routledge.

Halliday, M. A. K., \& Hasan, R. (I989). Language, context, and text: Aspects of language in a socialsemiotic perspective. Oxford: Oxford University Press.

Hartono, H. (2017). Mimikri dan hibriditasi dalam novel Burung-Burung Manyar karya YB Mangunwijaya. Paper presented at the PIBSI 39, Semarang.

Hastuti, N. (2018). Novel Bumi Manusia karya Pramoedya Ananta Toer kajian sosiologi sastra. Humanika, 25(I), 64-74. doi: https://doi.org/I0.I4710/humanika.v25iI.I8I28

Kramsch, C., \& Widdowson, H. (1998). Language and culture. Oxford: Oxford University Press.

Kusuma, B. A., \& Atikah, A. (2017). Analisis novel "Bukan Pasar Malam" karya Pramoedya Ananta Toer berdasarkan pendekatan postkolonial. Deiksis: Jurnal Pendidikan Bahasa dan Sastra Indonesia, 4(2), 8-2I. doi: http://dx.doi.org/I0.33603/deiksis.v4i2.636

Lane, M. (1996). This earth of mankind. New York: Penguin Books.

Leech, G. (1969). A linguistic guide to English poetry. Harlow: Longmans.

Leech, G., \& Short, M. (200I). Style in fiction: A linguistic introduction to English fictional prose foreign language. New York: Pearson Longman.

Mangunwijaya, Y. B. (I989). Burung-burung manyar: sebuah roman. Jakarta: Djambatan.

Muzakka, M. (2017). Novel Gadis Pantai karya Pramoedya Ananta Toer: Analisis hegemoni. ALA YASASTRA, I3(I), I3-20. doi: https://doi.org/I0.36567/aly.vI3iI.73

Nisa, I. N. (2019). Perbedaan kelas sosial pada novel Bumi Manusia karya Pramoedya Ananta Toer. Paper presented at the Prosiding Seminar Nasional Bahasa dan Sastra Indonesia (SENASBASA), Malang.

Rahayu, I., Muliawati, H., \& Pujiatna, T. (2019). Women's struggle against colonial imperialism in the Tetralogi Novel Bumi Manusia by Pramoedya Ananta Toer. Paper presented at the International Conference on Interdisciplinary Language, Literature and Education (ICILLE 20I8).

Ridwan, M. F., \& Sofianto, K. (2019). Rasisme dalam novel Bumi Manusia karya Pramoedya Ananta Toer: Kajian sosiologi sastra. Diglosia: Jurnal Pendidikan, Kebahasaan, dan Kesusastraan $\begin{array}{llll}\text { Indonesia, } & 3(2), & \text { I-II. } & \text { Retrieved }\end{array}$ https://www.jurnal.unma.ac.id/index.php/dl/article/view/I320

Said, E. (2003). Orientalism (25th Anniv.). New York: Vintage Books.

Subroto, D. E. (1997). Telaah linguistik atas novel Tirai Menurun karya NH Dini. Jakarta: Departemen Pendidikan dan Kebudayaan.

Sugono, D. (2008). Kamus Besar Bahasa Indonesia (4th ed.). Jakarta: Gramedia.

Taylor, J. G. (1983). The social world of Batavia: European and Eurasian in Dutch Asia. London: University of Wisconsin Press.

Toer, P. A. (2016). Bumi manusia. Jakarta Timur: Lentera Dirpantara. 